\title{
津波越流量抑制のための多重防潮堤の設置条件の実験的検討 Laboratory Experiment on Reduction of Tsunami Overflow due to M ulti Tsunami Barriers
}

\author{
二瓶泰雄 ${ }^{1} \cdot$ 柳沢舞美 $^{2} \cdot$ 釡池達也 ${ }^{3} \cdot$ 南 まさし $^{4}$ \\ Yasuo NIHEI, Maimi YA NAGISAWA, Tatsuya KA M AIKE and M asashi M INA M I
}

\begin{abstract}
Although use of multi tsunami barriers is one of fundamental countermeasures for tsunami, reduction of tsunami overflow due to multi barriers has not been investigated. In the present study, we performed a series of model tests in the laboratory to evaluate the effects of multi tsunami barriers on reduction of tsunami overflow and fluid force to buildings in its hinterland. The test results indicated that tsunami overflow in two barriers with the height $\mathrm{H}$ was smaller than that in a single barrier with same height $\mathrm{H}$. Furthermore the indices like overflow and fluid force in two barriers with relatively lower height are comparable to that in s single barrier with higher height, showing the fundamental performance of two barriers on reduction of tsunami overflow.
\end{abstract}

\section{1はじめに}

東日本大震災では, 岩手・宮城・福島3県において海 岸堤防総延長 $(300 \mathrm{~km})$ の約6割 $(190 \mathrm{~km})$ が全半壊し, 背後地に甚大な被害が発生した（内閣府，2012）。この 東日本大震災を契機として，我が国における津波対策と しては, 数十年から百数十年に一度の頻度の L 1 津波に対 して人命・財産を守る「防災」，あらゆる可能性を考慮 した最大クラスの巨大な津波（L2）には人命を守り経済 的損失を減らす「減災」，という視点に立脚する方針が 立てられた（中央防災会議，2011）。

これに基づいて，被災地ではレベル1津波に対応した 復興事業が計画され, 一部で展開されている。H26年1月 現在では, 宮城県仙台湾南部海岸では, 広大な砂浜上に 高さ7.2 T.P.mの三面コンクリート張り防潮堤が既に完成 しており, その背後には植樹エリアが整備されつつある (片野，2013).一方，三陸海岸では，レベル1津波の想 定高さが $10 \mathrm{~m}$ 以上となる地点も多く, 最大 $14.7 \mathrm{~m}$ が想定さ れている. それに加えて, 海岸部への人の往来を考慮し て防潮堤のり面の緩傾斜化 (3割勾配等) が検討され, 砂浜を覆い尽くす巨大防潮堤（高さ $10 \mathrm{~m}$ 以上, 幅 $50 \mathrm{~m}$ 以 上）の建設が計画されているが，住民合意が得られてい ない地区も多い（横山, 2013).

これらの問題を解決させる手段の一つとして, 巨大防 潮堤に代わる津波対策として, 津波越流量を抑制しつつ, 省スペースで，できるだけ天端高を抑えた防潮堤が望ま しい. それにより，元々の砂浜を中心とした海岸環境を

$\begin{array}{llll}1 & \text { 正会員 } & \text { 博(工) } & \text { 東京理科大学准教授理工学部土木工学科 } \\ 2 & \text { 非会員 } & \text { 修(工) } & \text { 清水建設(株) } \\ 3 \text { 会員 } & & \text { 東京都 } \\ 4 \text { 学生会員 } & & \text { 東京理科大学大学院理工学研究科土木工 } \\ & & \text { 学専攻修士課程 }\end{array}$

極力維持し，かつ，海を眺望できる範囲が広がるなどの 親水性向上に繋がる，これを実現するには，海岸堤防単 体では困難であり，背後の道路や鉄道などの盛土と組み 合わせた多重防潮堤が有用である（例えば, 毛利・丹治, 2012).この考え方は, これまでの海岸堤防という「線」 の防御のみから, 海側の防波堤や背後地の防潮林や道路. 鉄道盛土などを組み合わせた「面」の多重防御（国土交 通省，2013）を基礎としている。しかしながら, 多重防 潮堤による津波越流量抑制効果や適切な設置条件に関す る知見はほとんど得られていないのが現状である.

本研究では, 巨大な防潮堤を単体で設置するのではな く, 背の低い防潮堤をいくつか配置する “多重防潮堤” による津波減災効果を明らかにする。この防潮堤構造と しては, 非常に高い耐震性が実証され，急勾配のり面の 施工が可能なGRS (Geosynthetic-Reinforced Soil) 補強土 工法（Tatsuokaら，1997）を応用した “GRS多重防潮堤” を想定する. GRSを応用した防潮堤や河川堤防の耐越流 侵食性補強技術に関する検討は既に行っており，その有 用性は示されている（柳沢ら，2012；倉上ら，2013）. ここでは, 多重堤として二線堤を採用する場合を想定す る.この二線堤の津波減災効果を検証するために，造波 水路にて段波を起こし，1/50スケールの水理模型を用い た越流実験を行った。ここでは，木製の防潮堤模型を用 い, 防潮堤の勾配や高さ, 間隔等を変化させて防潮堤の 越流量を算定すると共に, 背後地の家屋被災特性に関係 する流体力等を求め, 各種条件下にて比較・検討した.

\section{2 実験方法}

本実験では, 柳沢ら（2012）と同様に，図-1に示すよ うな長さ36 m, 幅1 mの二次元造波水路（東京理科大学 所有）を用いた。ここでは，長さ10 m, 勾配1/20の斜面 を配置し，その沖側・岸側では水平床を設置した。 その 


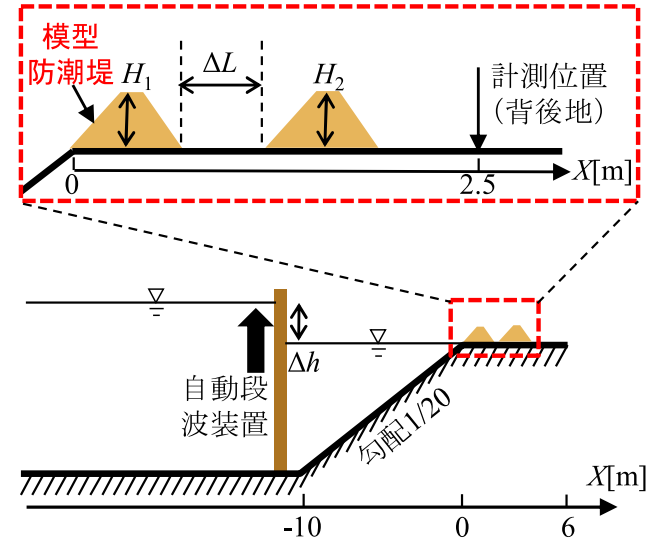

図-1 二次元大型造波水路の概略図

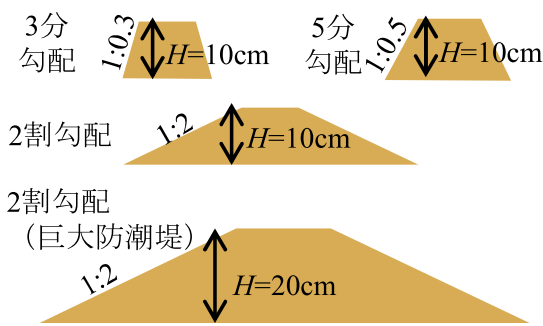

図-2 模型防潮堤の基本形状

沖側の水平床部分に油圧制御の自動段波装置を新規に設 置し, 扉の前後において最大50 cmの水位差 $\Delta$ hを設定可 能とした。越流実験で用いる防潮堤模型は木製であり, 海側の防潮堤設置位置を汀線 $(X=0 \mathrm{~m})$ とし, 陸側防潮 堤はそこから陸側に $\Delta$ L離れた位置に設置した。 木製模型 の縮尺を $1 / 50$ とし，レベル1津波対応を念頭にした「巨大 防潮堤」として高さ20 cmで表・裏のり面勾配を2割とし た。一方，“低め”の防潮堤として高さ $10 \mathrm{~cm}$ を基本とし て，のり面勾配を2割，5分，3分とする(図-2).なお表・ 裏のり面の勾配は同一としている.

越流実験では，水位差 $\Delta \mathrm{h}=20 \mathrm{~cm}$ もしくは30 cmの段波 を発生させ，この場合の防潮堤の越流時間は15秒程度で ある. 東日本大震災時の津波継続時間を $600 \mathrm{~s}$ とると, フルードの相似則より模型スケールでは85 s程度必要と なり，本実験では越流時間が短い，しかしながら，防潮 堤条件の差による越流特性を比較する分には問題ないと 思われる。

詳細な実験条件としては，表-1に示す様々な組み合わ せを設定し，防潮堤無（Case A) と単線堤 (Case B), 二 線堤（Case C-E）とした。単線堤としては，のり面勾配 を2割，5分，3分として，勾配の差による津波減災効果 を調べる。線堤条件に関しては, 防潮堤間の間隔 $\Delta L や$ 海側・陸側の防潮堤高さ $\left(\mathrm{H}_{1}, \mathrm{H}_{2}\right)$ をいくつか設定した. また，表中に示すように，段波の水位差 $\Delta \mathrm{h} は 20 \mathrm{~cm}$ と
表-1 越流実験の条件

\begin{tabular}{|c|c|c|c|c|c|c|}
\hline \multirow{2}{*}{ Case } & \multirow{2}{*}{$\begin{array}{c}\Delta \mathrm{h} \\
{[\mathrm{cm}]}\end{array}$} & \multicolumn{2}{|c|}{ 勾配 } & \multicolumn{3}{|c|}{ 単位:cm } \\
\hline & & 海側 & 陸側 & $\Delta \mathrm{L}$ & $\mathrm{H}_{1}$ & $\mathrm{H}_{2}$ \\
\hline A 1 & \multirow{8}{*}{$\begin{array}{l}20 . \\
30\end{array}$} & \multicolumn{5}{|c|}{ 防潮堤なし } \\
\hline B1 & & 2割 & - & - & 10 & - \\
\hline B2 & & 5分 & - & - & 10 & - \\
\hline B3 & & 3分 & - & - & 10 & - \\
\hline B 4 & & 2割 & - & - & 20 & - \\
\hline $\mathrm{C} 1$ & & 2割 & 5分 & 100 & 10 & 10 \\
\hline $\mathrm{C} 2$ & & 5分 & 3分 & 100 & 10 & 10 \\
\hline $\mathrm{C} 3$ & & 3分 & 5分 & 100 & 10 & 10 \\
\hline D1 & \multirow{13}{*}{30} & 2割 & 5分 & 50 & 10 & 10 \\
\hline D2 & & 2割 & 5分 & 150 & 10 & 10 \\
\hline D3 & & 2割 & 5分 & 200 & 10 & 10 \\
\hline D4 & & 3分 & 5分 & 50 & 10 & 10 \\
\hline D5 & & 3分 & 5分 & 150 & 10 & 10 \\
\hline D6 & & 3分 & 5分 & 200 & 10 & 10 \\
\hline E1 & & 2割 & 5分 & 100 & 10 & 12.4 \\
\hline E2 & & 3分 & 5分 & 100 & 12.4 & 10 \\
\hline E3 & & 3分 & 5分 & 100 & 14.8 & 10 \\
\hline E4 & & 3分 & 5分 & 100 & 17.2 & 10 \\
\hline E5 & & 3分 & 5分 & 100 & 10 & 12.4 \\
\hline E6 & & 3分 & 5分 & 100 & 10 & 14.8 \\
\hline E7 & & 3分 & 5分 & 100 & 10 & 17.2 \\
\hline
\end{tabular}

$30 \mathrm{~cm}$ とした場合（Case A-C）と 30cmのみの場合（Case D,

E）がある.

実験における計測項目・方法としては，容量式波高計 （HA-1106，東京計測（株）製）により水位を，電波流速 計（RYUKAN，横河電子機器（株）製）により流速をそ れぞれ計測した，計測地点は，水位に関しては，沖側 $(X=-8 \mathrm{~m})$, 防潮堤直上 $(X=0 \mathrm{~m})$, 背後地 $(X=2.5 \mathrm{~m})$ で あり，流速については背後地 $(X=2.5 \mathrm{~m})$ のみとする. また，防潮堤の越流状況を側面からビデオ撮影した。 様々な防潮堤条件に扔ける津波減災効果を把握する指標 としては, 背後地に打ける水深 $\mathrm{h}$ 流速 $v$ に加えて, 越流 量Q, 流体力F, モーメント指標M（田中ら，2012）とし, 後者の3つは次式で表わされる.

$$
\begin{aligned}
& Q=v h B \\
& F=0.5 \rho g W_{b}\left[h\left(1+\frac{F_{r}}{2}\right)\right]^{2} \\
& M=v^{2} h^{2}
\end{aligned}
$$

ここで, $\mathrm{B}$ : 水路幅, $\rho$ : 水の密度, $\mathrm{W}_{\mathrm{b}}$ : 建物の幅, $\mathrm{Fr}$ ：

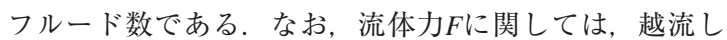
ない建物を想定し，その幅 $\mathrm{W}_{\mathrm{b}}$ 1 mとして与え，実質的 
に単位幅あたりの流体力を求めた

\section{3. 結果と考察}

\section{（1）のり面勾配が津波越流特性に及ぼす影響（単線堤）}

様々な二線堤条件における津波越流特性を比較・検討 する前に，まず，単線堤に扔ける表・裏のり面勾配の違 いによる津波越流特性を把握する。図-3は防潮堤無 (Case A1）と表・裏のり面共に2割，5分，3分勾配（Case B1, B2，B3）に関する背後地（X=2.5m）での水深と流速の 時間変化を示す。これょり，防潮堤を置いたケースの水 深は，防潮堤無よりも小さくなっており，また，勾配に よる差異は見られない，一方，流速に関する大小関係は， 逆に，防潮堤無＜有（CaseB2，B3）<有（CaseB1）と なっている。これは，防潮堤を乗り越えた水塊の位置工 ネルギーが速度エネルギーに変わる分だけ，防潮堤有に おける流速が増加したものと考えられる。また，のり面 勾配が急なケース（Case B2，B3）における流速は，緩 勾配のCase B1よりも小さくなった。これは3分，5分の裏 のり面側では剥離流れが生じ，それによりエネルギー減 衰しているためである。な挔，水深の時系列変化に示さ れているように，図中矢印の一波目の後には，反射波が 発生している.

上述したのり面勾配を変えた実験条件における総越流 量比と背後地における流体力比を算出した結果を表-2に 示す。ここでは, 各ケースに打ける結果を防潮堤無（Case A1）の結果で除したものを比の形で表しており，段波の 第一波の遡上期間中のみの結果を用いる。これより，総 越流量比としては，全てのケースで0.64以下となってい るが，のり面勾配が3分や5分のケースが相対的に小さい. これは，図-3に示すように，流速の差を反映した結果と なっている，一方，流体力比についても，のり面勾配が 3分と5分の方が2割の場合よりも小さくなっており，流 速や総越流量比の結果と対応している。また，のり面勾 配が2割の場合には，流体力比は1.17となり，緩やかな防 潮堤を越流する場合には，防潮堤が無い時よりも大きな 流体力が作用する可能性があることが示唆された。

\section{(2) 二線堤における流況と越流量}

次に，二線堤における基本的な流況を把握するために， 二つの防潮堤を越流しているときのビデオ撮影画像を図 -4に示す。ここでは，海側・陸側防潮堤ののり面勾配が3 分・5分の場合（Case C3）と2割・5分の場合（Case C1） を例示している。これを見ると，津波が海側の防潮堤に 到達すると，津波の跳ね上がりが発生し，その後，海側 防潮堤の裏のり面や二つの防潮堤の間に着水する。 その 先端部分が陸側の防潮堤に到達した後，ボアが発生し， そのボアは海側へ伝播していく。ボアが海側防潮堤に到 達した後は，準定常的な越流状況が形成されている，基

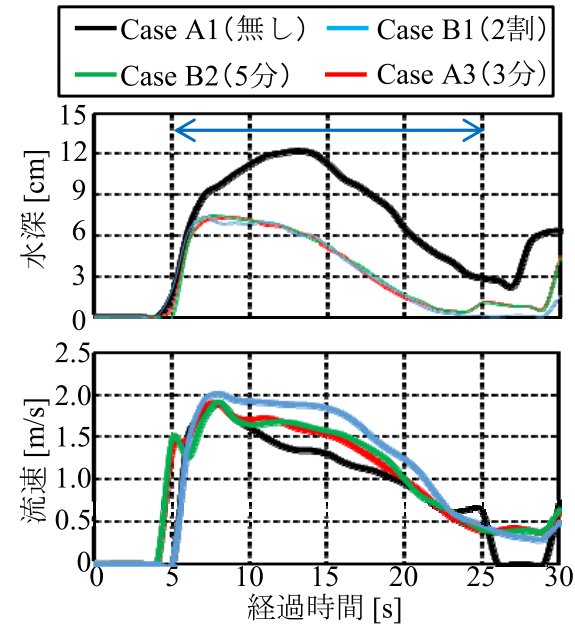

図-3 防潮堤の無いケースと単線堤における水深 (上) と流速 (下)の時間変化(背後地 $X=2.5 \mathrm{~m}$ 地点)

表-2 様々なのり面勾配条件における総越流量比と流体力比 の比較

\begin{tabular}{c|c|c}
\hline & 総越流量比 & 流体力比 \\
\hline 2割 & 0.632 & 1.168 \\
\hline 5分 & 0.570 & 0.885 \\
\hline 3分 & 0.579 & 0.857 \\
\hline
\end{tabular}

本的な流況パターンは，CaseC1とC3で大きな差は見られ ないが，最初の跳ね上がりの高さは，海側防潮堤が急勾 配なCase C3の方が大きくなり, 結果として, 着水時の乱 れもCase C3の方が顕著となっている，その影響を受けて 陸側防潮堤到達時に扔ける跳ね上がりも，Case C3の方が 大きかった (図面省略)。また，ボアの発生状況につい ては，明確な差異は見られなかった。

二線堤3ケースにおける総越流量を算出した結果を図-5 に示す。ここでも，表-2と同じく，一波目のみの総越流 量を算出し，それを防潮堤無（CaseA1）の結果で除した ものを表示している。また，合わせて2割勾配の単線堤 で高さ $10 \mathrm{~cm}$ と $20 \mathrm{~cm}$ (CaseB1，B4）の結果も図示する. これより, 二線堤の総越流量は, 同一高さの単線堤（B1） より小さくなっている。 また，単線堤と二線堤の越流量 の差は，二線堤間における貯留量を上回っている。ささら に，3ケースの二線堤の結果としては，概ね類似してい るが，Case C3が相対的に小さくなっている．なお，二線 堤は, 高さが倍の単線堤（Case B4）よりも大きな越流量 を記録しており，二線堤の更なる設置条件の検討が必要 である。

\section{（3）防潮堤間の距離 $\Delta L$ と防潮堤高さの効果}

二線堤の様々な設置条件下に扔ける総越流量を比較し たものを図-6に示す。ここでは，防潮堤間の距離 $\Delta \mathrm{L}$ と防 


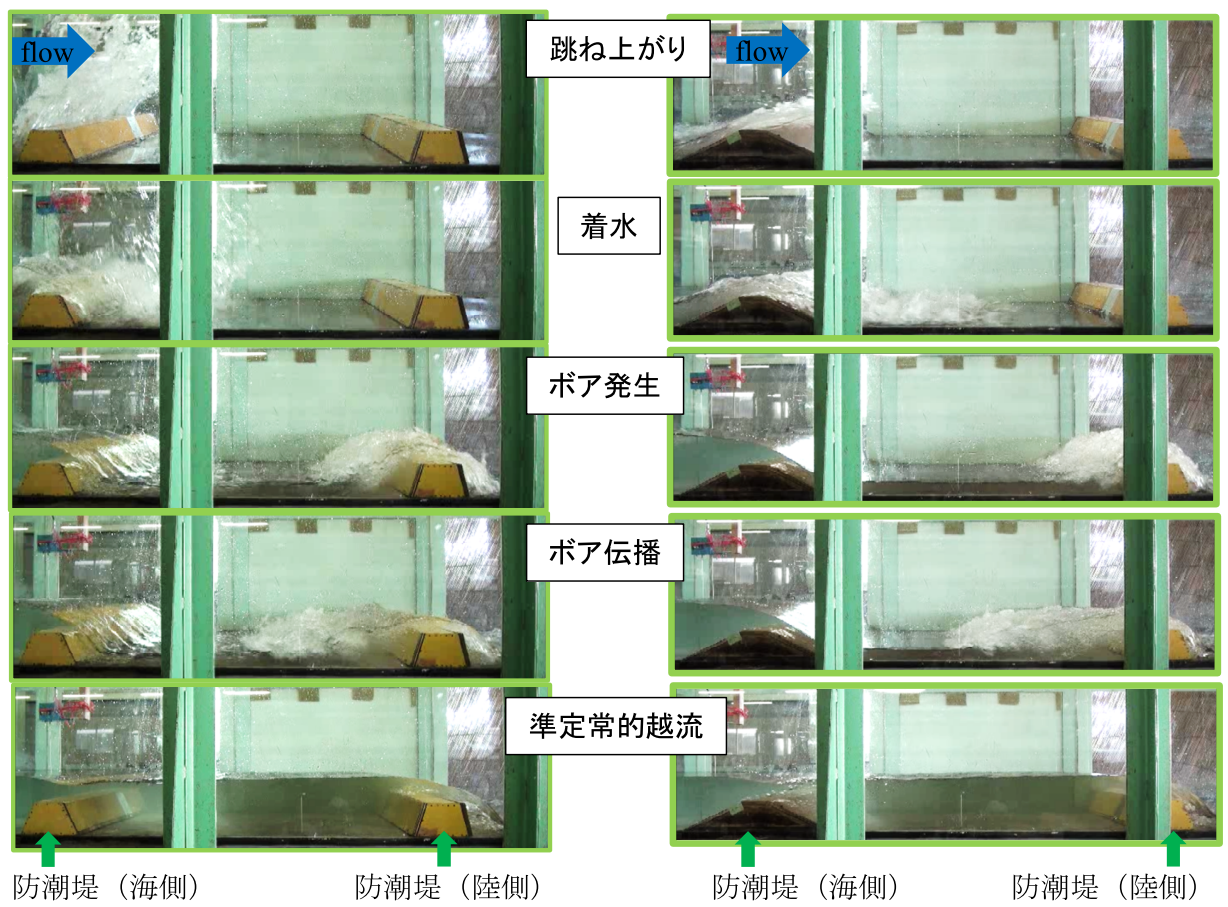

(a) Case $\mathrm{C} 3$

(b) Case $\mathrm{Cl}$

図-4 二線堤における流況パターン

潮堤高さ $\mathrm{H}_{1}, \mathrm{H}_{2}$ を変えており, 二線堤の勾配の組合せと しては，Case C1，C3と同じものを選定している。また， 図中には, 防潮堤無 (CaseA) と単線堤 (高さ10 cm, Case B1; 高さ20 cm, Case B4）の結果も表示している. これょり，防潮堤間距離 $\Delta \mathrm{L}$ をきくすると，二線堤の勾 配の組合せによらず, 総越流量は減少し, $\Delta \mathrm{L}=200 \mathrm{~cm}$ （実 スケールで $100 \mathrm{~m}$ ）では, 高さ $20 \mathrm{~cm}$ の単線堤の結果に近 づくものとなっている. また, 両ケースともに, 前述し たように, 防潮堤間の貯留量以上に総越流量を削減して いる。これは，遡上してきた津波のエネルギーは，ボア 形成に伴って防潮堤間において減衰する。また，ボア遡 上などの戻り流れの形成により，二線堤において越流量 が削減されており，その効果は防潮堤間の距離 $\Delta \mathrm{L}$ 共に 増加しているものと考元られる.

一方, 防潮堤高さを高くすると, 総越流量は減少し, 特に $\mathrm{H}_{1}=17.2 \mathrm{~cm}$ (Case E4) では高さ $20 \mathrm{~cm}$ の単線堤より も越流量を減らせた。 この防潮堤の高さに関しては, 陸 側の防潮堤よりも海側のほうが効果が大きい。これは, 津波一波目の到達時に打ける跳ね上がりやそれに伴う反 射波の形成などによるものと推察される。

前述した全ての津波越流指標に関する結果をレーダー チャートでまとめたものを図-7に示す。ここでは，各 ケースに打ける結果を単線堤の高さ20 cm（Case B4）に 㧍ける結果で除したものを表示している. 図中の対象

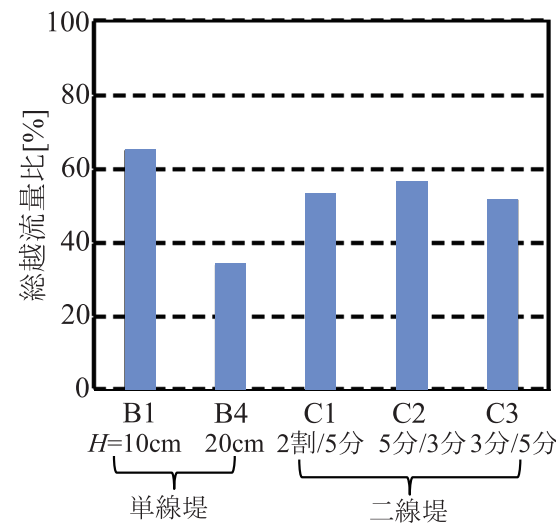

図-5 二線堤における総越流量比の比較

ケースとしては，二線堤ののり面勾配が海側3分，陸側5 分を基本として (Case C 3), 海側・陸側の防潮堤高さ $\mathrm{H}_{1}$, $\mathrm{H}_{2}$ や防潮堤間の距離 $\Delta L$ を変えている。これより, 海側の 防潮堤高さが17.2cmの場合（Case E4）では全ての指標が 1を下回り, 巨大防潮堤（Case B4）よりも津波減災効果 が高いことが分かる。また，Case E3やCase D6などにお いては，比較的良好な結果となっている。このように， 多重防潮堤の設置法を工夫することにより, 防潮堤高さ を減らしても津波越流量を抑制でき, かつ, 背後地の建 物への流体力を減らすことができることから，多重防潮 堤が有用な津波減災効果を発揮することが示された。 


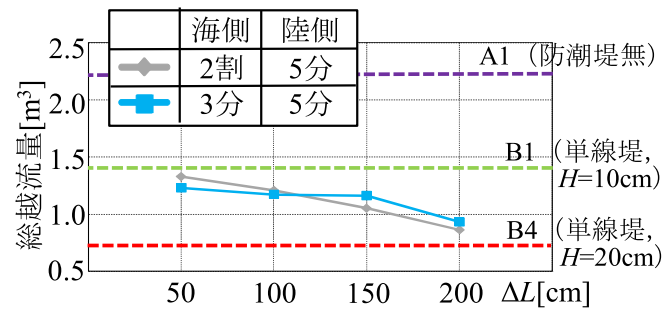

(a) 防潮堤間の距離 $\Delta L$

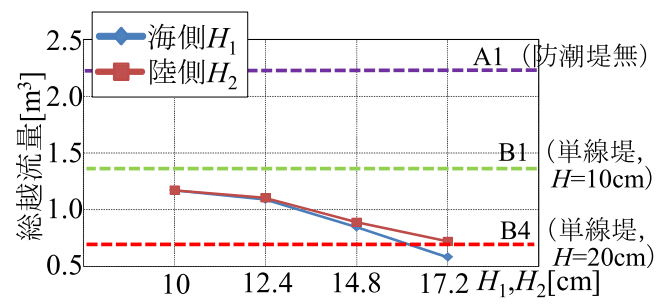

(b) 防潮堤高さ $H_{1}, H_{2}$

図-6 様々な二線堤条件下における総越流量

\section{4. まとめ}

本研究で得られた主な結論は, 以下の通りである.

1）単線堤では, 急勾配ののり面 (3分, 5分) の方が, 緩勾配（2割）のケースよりも津波越流量や背後地家 屋への流体力を抑制し得ることが示された.

2）二線堤の場合, 同一高さの単線堤よりも津波越流量 を抑制できている。 また, 単線堤・二線堤の越流量の 差は, 二線堤間の貯留量を上回る

3）様々な設置条件下における津波越流指標を算出した 結果, 二線堤条件の工夫により, 防潮堤高さを減らし ても津波越流量を抑制でき，かつ，背後地の建物への 流体力を減らすことができ, 多重防潮堤が有用な津波 減贸効果を発揮することが示された。

謝辞：本研究の一部は, 三井物産環境基金·2011年度復 興助成（研究代表者：二瓶泰雄）と科学研究費補助金. 基盤研究（B）（研究代表者：二瓶泰雄）によって実施さ れた.ここに記して深甚なる謝意を表します.

\section{参 考 文 献}

片野正章（2013）：東日本大震災で被災した海岸堤防の復旧状 況について - 仙台湾南部海岸の事例 -, 土木学会誌,

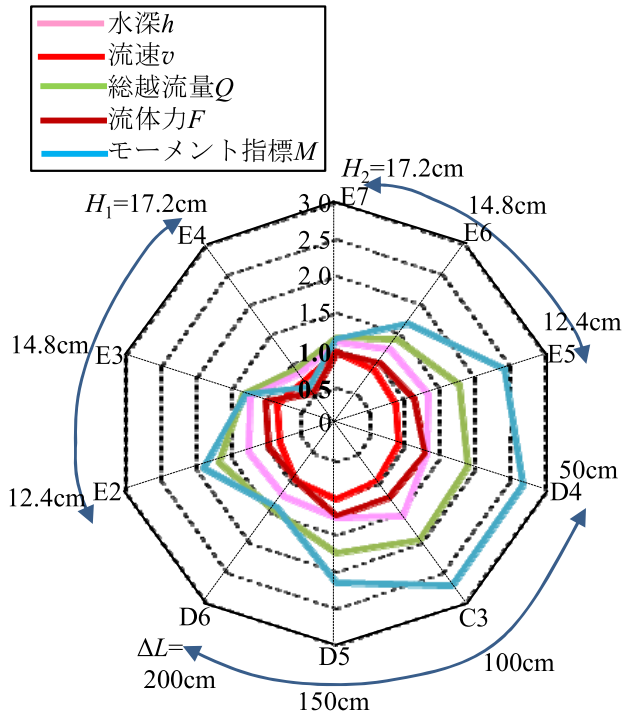

図-7 全ての津波越流指標に関するレーダーチャート (Case C3を基本とし, $\mathrm{H}_{1}, \mathrm{H}_{2}$ と $\Delta \mathrm{L}$ を変化)

Vol.98, No.10, pp.40-43.

倉上由貴 ·二瓶泰雄 - 矢田孝次朗 - 山崎達也 - 山口晋平 · 川 邊翔平・菊池喜昭・龍岡文夫（2013）：耐越流侵食性向上 のための河川堤防補強技術の提案, 土木学会論文集B1（水 工学), Vol.69, N0.4, pp.I_1219-I_1224.

国土交通省（2013）：平成23年度国土交通白書，第 I 部第1章 第3節.

田中規夫・八木澤順治・飯村耕介・近藤康太（2012）：津波に よる海岸林および流失家屋が家屋被害に与える影響, 土 木学会論文集B2（海岸工学）Vol.68, N o.2, pp.I_301I_306.

中央防災会議（2011）：「東北地方太平洋沖地震を教訓とした 地震・津波対策に関する専門調査会」中間とりまとめに 伴う提言 〜今後の津波防災対策の基本的考え方について $\sim$, http://www.bousai.go.jp/kohou/oshirase/pdf/teigen.pdf (閲覧日：平成25年5月17日).

内閣府 (2012) : 平成23年度防災白書, 第 I 部第1編第2章.

毛利栄征·丹治 肇 (2012) : 平成23年 (2011 年) 東北地方太 平洋沖地震における海岸堤防の後背農地による津波減勢, 農村工学研究所技報, 第213 号, pp.105-116.

柳沢舞美 ·二瓶泰雄・山口晋平・川邊翔平・龍岡文夫 (2012)： 海岸砂丘と補強盛土技術を組み合わせた新形式防潮堤の 提案, 土木学会論文集B2 (海岸工学), Vol.68, N o.2, pp.I_886-I_890.

横山勝英 $(201 \overline{3})$ : 三陸リアス式海岸の水際における防潮堤と 土地利用, 海洋と生物, Vol.35, N o.6, pp.592-597.

Tatsuoka, F., M, Tateyama, T. U chimura and J. Koseki (1997) : Geosynthetic-reinforced soil retaining walls as important permanent structures, 1996-1997 M ercer Lecture, Geosynthetic International, Vol.4, N o.2, pp.81-136. 